\title{
The Effect of Employee Engagement and Job Satisfaction on Effectiveness Through Organizational Changes: A Case Study of BLUD, East Java Province
}

\author{
Taufiq Mansur, Anwar Sanusi, and Boge Triatmanto \\ University of Merdeka Malang, Indonesia
}

\begin{abstract}
Effectiveness in managing an organization is one of the important things that management wants to achieve, especially in connection with a dramatic or sudden organizational change that does not involve all components in the organization, in this case operational employees who will eventually be the backbone of the success or failure of organizational change. The attitude of employee engagement and job satisfaction of employees is expected to have a major influence on organizational effectiveness. The research objective is to analyze the effect of Employee Engagement, Job Satisfaction and organizational change on Organizational Effectiveness. The research was conducted at the Technical Implementation Unit of the Regional Public Service Agency (BLUD) in the Department of Agriculture and Food Security, East Java Province, with the number of respondents as many as 111 people. Based on the Path analysis, the research results show that the existence of Employee Engagement and Job Satisfaction of employees is very influential on Organizational Effectiveness, then job satisfaction also supports organizational change, so that employee job satisfaction and organizational change will have a greater effect than if there is no organizational change. But on the other hand, those related to employee engagement tend to have a big influence on organizational effectiveness if directly, without any organizational changes. then job satisfaction also supports organizational change, so that there is employee job satisfaction and added with organizational changes, the effect is greater than if there was no organizational change. But on the other hand, those related to employee engagement tend to have a big influence on organizational effectiveness if directly, without any organizational changes. then job satisfaction also supports organizational change, so that there is employee job satisfaction and added with organizational changes, the effect is greater than if there was no organizational change. But on the other hand, those related to employee engagement tend to have a big influence on organizational effectiveness if directly, without any organizational changes.
\end{abstract}

Keywords: Employee Engagement, Job Satisfaction, Effectiveness, Organizational Change.

\section{INTRODUCTION}

Every work organization will certainly pay more attention to effectiveness, especially in anticipating the changing economic environment in order to compete in global competition. All parties in the organization must understand this effectiveness, even though this is not easy to do, but hopefully it will be able to support efforts to achieve organizational goals and objectives and maintain the continuity and future of the organization (Mullins, 2011) [1].

Organizational effectiveness can be expressed as the level of success of the organization in an effort to achieve its goals and objectives. The effectiveness of an organization is the level of organizational achievement that is influenced by individuals, groups and also structures in the organization. An organization that can achieve its goals optimally is called an effective organization. The greater the result, the more effective it is. Effective also means that the goals that have been set can be achieved optimally.

A formal organization can be said to be a network that is constantly changing and related to the behavior of the humans in it, so it is necessary to understand the behavior of human resources with other variables, such as environmental factors both internal and external, management processes and employees themselves, which are the whole will affect the running of the organization.

There are various kinds of factors that can affect the effectiveness of an organization, one of which is job satisfaction. Job satisfaction is a general attitude of an individual towards his job, a person with a high level of job satisfaction shows a positive attitude towards the job, a person who is dissatisfied with his job shows a negative attitude towards the job (Stepen P Robbins \& Judge, 2008) [2]. Employee job satisfaction is a factor that is considered important, because it can affect the running of the organization as a whole. According to (Fatimah, Amiraa, \& Halim, 2011), job satisfaction is the most researched concept studied in relation to industrial and organizational psychology. this is because job satisfaction is related to factors that are important in an 
effort to create a better organization [3]. The satisfaction felt by employees at work is an indication that employees have a happy feeling in carrying out work tasks. If employees have high job satisfaction, these employees will work more enthusiastically and are motivated to do a better job so that it can encourage organizational productivity.

For organizations, employee job satisfaction must receive attention and fulfillment of this is especially the task of the managerial ranks in the organization. Job satisfaction is also related to outcomes such as performance, so that if job satisfaction is higher, it will generate enthusiasm for work. With regard to Job Satisfaction, at the Technical Implementation Unit (UPT) of the Regional Public Service Agency (BLUD) in the Department of Agriculture and Food Security of East Java Province, since the beginning of 2019 a performance allowance has been given to all employees, where the amount of the allowance is adjusted to the class of position and performance. . So that this research is interesting to do, namely whether the existence of this performance allowance, can encourage satisfaction for employees at work, which ultimately leads to increased organizational effectiveness.

Apart from job satisfaction, another factor, namely Employee Engagement, is also considered capable of influencing organizational effectiveness. Employee Engagement is a positive attitude that individual employees have towards the organization and organizational values, so that an employee who feels involved will be aware of the business context of the organization, and can work well with colleagues or superiors as an effort to improve performance for the benefit of the organization ( Robinson, Perryman, \& Hayday, 2004) [4].

In order to produce a positive performance increase in an organization, management is advised to pay more attention or guidance to increase employee engagement, because this factor is often touted as the key to the success and competitiveness of an organization. Engagement is a factor that is very necessary for organizations today to face the various challenges that exist. Engagement is also a major driver for individual attitudes, behavior and performance as well as performance, productivity, retention, financial performance of an organization. Employees who have a high sense of Employee Engagement will be generous and have self-belonging to the company or organization where they work.

In an organization, it is not uncommon for many changes to occur, these changes can be changes that have positive and negative impacts. Organizational change is a change that cannot be avoided by organizations, whether for profit or non-profit organizations, public and private organizations, or large and small organizations. Organizational changes can be caused by various factors, both factors that come from within the organization and factors that come from the changing environment. Factors from within the organization can be in the form of new equipment, changing goals, and employee attitudes and behavior. Meanwhile, factors originating from the environment can be in the form of technological developments, economic conditions, socio-political changes and so on. There are changes in the organization.

One form of organizational change is the change in several Technical Implementation Units (UPT) under the East Java Province Agriculture and Food Security Agency to become Regional Public Service Bodies (BLUD), which is based on the Decree of the Governor of East Java No. 188/518 / KPTS / 013/2017, some of these UPTs are UPT. Horticultural Seed Development, UPT. Development of Rice and Vegetable Seeds and UPT. Development of Food Crops and Horticulture Agribusiness. The initial spirit of this change was that the local revenue-producing UPT could be more optimal in managing its finances so as to support general organizational effectiveness. As is well known, one of the agendas for reforming state finances is a shift from budgeting using traditional patterns to budgeting based on performance. Through this performance basis, the orientation of the use of government resources is no longer oriented to input, but to output. This is important considering that government resources are increasingly limited, but they are required to meet the demands of development needs that are increasing and becoming increasingly complex.

In general, public service agencies can be classified into 3 (three) forms, namely the first, an ordinary bureaucratic agency with a limited degree of autonomy and independence that can be said to be nonexistent, then the second is BLUD as a semi-autonomous institution, and the third, namely BUMD as a public / state institution that is truly autonomous in managing every resource and making decisions (Lukman, 2013) [6]

In Article 1 paragraph 23 of Law Number 01 of 2004 concerning State Treasury which states that the Public Service Agency (BLU) is an agency within the Government which is formed to provide services to the community in the form of providing goods and / or services that are sold without prioritizing profit-seeking ( not-for-profit) and in carrying out its activities based on the principles of efficiency and productivity. In addition, through BLUD, it will ensure flexibility in financial management, namely in the form of functional income that can be directly used for service operational activities without having to be deposited in the regional treasury first. In addition, the management autonomy given will encourage changes in management patterns and paradigms of all elements in the BLUD organization so that in the end the level of community service can be 
increased in a more professional, effective and efficient manner. Through this understanding, the central government encourages local governments to immediately form a Regional Public Service Agency (BLUD), this is accommodated in Article 346 of Law Number 23 of 2014 concerning Regional Government. Then through Government Regulation of the Republic of Indonesia Number 23 of 2005 concerning Financial Management of Public Service Bodies and Regulation of the Minister of Home Affairs of the Republic of Indonesia Number 79 of 2018 concerning Regional Public Service Bodies, Local governments are required to make an inventory of SKPDs or Work Units in SKPD which operationally provide direct services to the community in order to implement PPK-BLUD. So that several Technical Implementing Units under the Department of Agriculture and Food Security of East Java Province turned into Regional Public Service Bodies (BLUD).

As a new concept, and starting to be developed in Indonesia, the development of the transformation of UPT into BLUD is interesting to study. Considering the importance of the UPT's position as the forefront of public services in East Java, this transformation is part of the steps of the East Java Provincial Government to overcome the budget constraints (fiscal space) that is being experienced as well as trying to optimize the strength it has to spur the quality of public services. As something new, it is necessary to study how these changes affect organizational effectiveness, with other supporting factors as described briefly above.

\section{LITERATURE REVIEW}

\subsection{Employee Engagement}

Employee Engagement is a positive attitude that individual employees have towards the organization and organizational values, so that an employee who feels involved will be aware of the business context of the organization, and can work well with colleagues or superiors as an effort to improve performance for the benefit of the organization. (Robinson et al., 2004) [4]. Employee engagement is an important concept in organizational behavior and has received significant attention in various academic studies(Hanaysha, 2016) [7]. Employee engagement is also known as employee attachment to the company, which is a very important aspect and must be considered carefully by the company because with a strong sense of attachment, the employee's commitment to the company will be higher.

\subsection{Job satisfaction}

Job satisfaction is the most researched and studied concept in relation to industrial and organizational psychology, this is because job satisfaction is related to factors that are important in an effort to create a better organization (Fatimah et al., 2011) [3] . Locke(Luthans, 2012) revealed that job satisfaction is a cognitive, affective, and evaluative reaction or attitudes and statements that describe a pleasant or positive emotional state resulting from a person's assessment of his job or work experience [8]. According to (Robbins \& Judge, 2008), job satisfaction is a positive feeling about work, which results from an evaluation of its characteristics, a person with a high level of job satisfaction has positive feelings towards his job and conversely someone with a low level of satisfaction has negative feelings [2].

\subsection{Organizational Effectiveness}

An organization is an association between two or more people, which between them collaborates and has a bond in order to achieve a common goal (Irianto, 2011) [9]. Meanwhile, the definition of an organization according to (Gibson, Ivancevich, \& Donnelly, 1989) is a unit that allows people to achieve goals that cannot be achieved individually by individuals [10].

Meanwhile, in the context of organizational behavior, according to(Gibson et al., 1989)effectiveness is the optimal relationship between production, quality, efficiency, flexibility, satisfaction, the nature of excellence and development [10]. Organizations consist of individuals and groups, therefore organizational effectiveness also consists of individual and group effectiveness, but not only the sum of the two, more than that, namely synergy between individuals and groups so as to get optimal organizational effectiveness.

\subsection{Organizational Change}

It was stated by (Triatmanto \& Nursyamsi, 2011), that today the phenomenon of organizational change has been oriented to how conditions and demands exist in the market, then related to production and behavior in organizations, so that this presents a special challenge for organizations to continue to develop. continuous human resources, both customers and operations as well as people involved in the organization [11]. Organizational change is a move from a static condition where there is no change, addition or improvement to the desired form or situation and more suitable for the environment.(Nelson, 2003) [12].

\subsection{Hypothesis}

Based on the theoretical foundation and conceptual framework that has been described, the following research hypotheses can be formulated:

1) It is suspected that employee engagement and job satisfaction have a significant effect on organizational changes at UPT. BLUD in the Department of Agriculture and Food Security, East Java Province. 
2) It is suspected that employee engagement and job satisfaction have a significant effect on organizational effectiveness at UPT. BLUD in the Department of Agriculture and Food Security, East Java Province.

3) It is suspected that organizational change has a significant effect on organizational effectiveness at UPT. BLUD in the Department of Agriculture and Food Security, East Java Province.

4) It is suspected that employee engagement and job satisfaction have a significant effect on organizational effectiveness through organizational changes at UPT. BLUD in the Department of Agriculture and Food Security, East Java Province

\section{RESEARCH METHODS}

\subsection{Operational Definition of Research Variables}

a. Employee Engagement

Employee Engagement is a positive attitude from individual employees towards the organization and a feeling of being bound to their work so that they always devote all their abilities in completing their work and are able to work together with other employees to support the performance of the UPT. BLUD, with indicators:
a) Spirit (Vigor)
b) Dedication
c) Absorption

b. Job satisfaction

Job Satisfaction is the feeling and attitude of UPT employees. BLUD on work experience and compensation provided, with indicators:
a) Wage
b) The work itself
c) Promotion
d) Supervision / Supervisor
e) Team work
f) Working Conditions

c. Organizational Change

Organizational Change is a change in the organizational structure, work operations and classifications of employees based on their performance at the UPT. BLUD, with indicators:
a) Structure Change
b) Technology changes
c) Physical Arrangement Changes
d) Change of People

d. Organizational Effectiveness

Organizational effectiveness is efficiency in the continuity of work operations as well as ease in adjusting work plans to optimize the resources owned to support the production results of the UPT. BLUD, with the indicators:
a) Production result
b) Efficiency
c) Satisfaction
d) Adjustments
e) Continuity

\subsection{Population and Sample}

Population is a generalization area consisting of objects or subjects that have certain qualities and characteristics set by researchers to study and then draw conclusions (Sugiyono, 2017) [13]. The population referred to in this study is all employees of the East Java Province Agriculture and Food Security Service, who are in the Technical Implementation Unit (UPT) of the Regional Public Service Agency (BLUD), where the total number is 193 people. The sample is part of the number and characteristics of the population. Taking the sample size in this study using the Slovin formula, in order to obtain a total sample of 130 people. The sampling technique uses simple random sampling technique, namely the technique of taking samples from members of the population which is done randomly without paying attention to the strata in the population.(Sugiyono, 2017) [13].

\subsection{Data analysis technique}

The data analysis technique used is path analysis. Path Analysis according to Sugiyono (2017), is an extension of regression analysis, where path analysis is used to describe and test the relationship model between variables in the form of causation (not an interactive / reciprocal relationship) [13]. Path analysis alone does not determine causal relationships and also 
cannot be used as a substitute for researchers to see the causality relationship between variables. The causality relationship between variables has been formed with a model based on a theoretical basis. What path analysis does is determine the pattern of relationships between three or more variables.

\section{RESULTS AND DISCUSSION}

\subsection{Path Analysis}

The results of the path analysis will be used to see the influence between variables by looking at the level of significance between variables and the relationship between variables. To see the effect between variables, it can be seen from the value of the Adjusted R Square (r2) by calculating the amount of the Coefficient of Determination (KD) using the formula KD $=\mathrm{r} 2 \mathrm{x} 100 \%$. Meanwhile, to see the level of significance between variables used the research Sig, if the research Sig is less than 0.05 (Sig $<0.05)$, it is stated that there is a significant influence between variables. If the Sig value of the study is greater than the value of 0.05 (Sig> 0.05), it is stated that the influence between variables is not significant or it can also be seen by using the t test. If the value of $t$ is greater than $t$ table ( $t$ count $>t$ table) then the influence between variables is significant.

The development of a theoretical model is carried out based on the influence relationship between variables, which is then made a model in the form of a path diagram as follows:

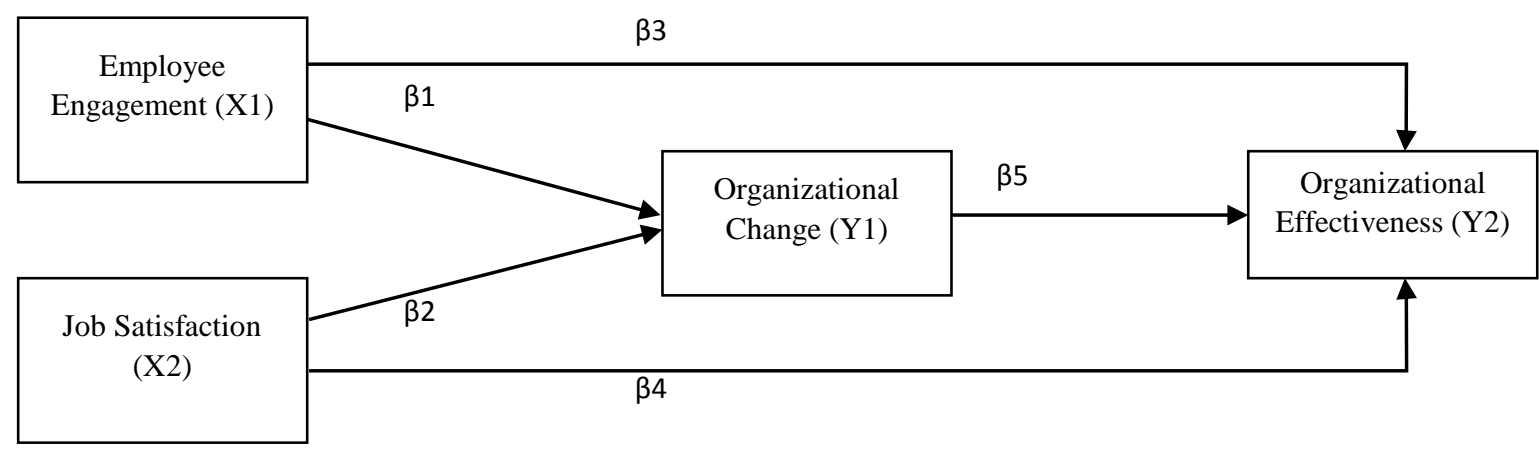

Figure 1. Path diagram of the theoretical research model

Based on the path diagram as seen in Figure 1, then expressed in the following equation:
1. $\mathrm{Y} 1=\beta 1 \mathrm{X} 1+\beta 2 \mathrm{X} 2+\varepsilon \mathrm{i}$
2. $\mathrm{Y} 2=\beta 3 \mathrm{X} 1+\beta 4 \mathrm{X} 2+\beta 5 \mathrm{Y} 1+\varepsilon \mathrm{i}$
(Model 1)
(Model 2)

Furthermore, the calculation of the path coefficient in this study uses standardized regression analysis by looking at the effect simultaneously and partially on each equation. The method used is Ordinary Least Square (OLS), that is, the least squares method is calculated using SPSS software version 24:

\section{a. Model Test}

Testing of the equation model is carried out to see whether our regression model is good / significant or not good / non significant. If the model is significant, it can be used to predict, on the other hand, if it is non-significant, the regression model cannot be used to predict. Where the results of the regression test results of research data processing are shown in the table below:

Table 1. Simultaneous F test results

\begin{tabular}{|l|l|l|l|l|}
\hline \multicolumn{1}{|c|}{ Model } & \multicolumn{1}{|c|}{ F count } & \multicolumn{1}{c|}{ F table } & sig F & Information \\
\hline Model 1 & 7,413 & 3,080 & 0.001 & Significant \\
\hline Model 2 & 25,952 & 2,689 & 0.000 & Significant \\
\hline
\end{tabular}

Based on table 1 above, it can be concluded that Model 1 has an F value of 7,413 with a sig of 0.001 . Because the value of Fcount is less than Ftable or sig is greater than $\alpha 5 \%$, it can be concluded that in the first model, the exogenous variables Employee Engagement (X1) and Job Satisfaction (X2) have a significant effect on the endogenous variables of Organizational Change (Y1).

Furthermore, for Model 2, the Fcount value is 25,952 with a sig of 0,000. Because the value of Fcount is greater than Ftable or sig is smaller than $\alpha 5 \%$, it can be concluded that in model 2, the exogenous variables Employee Engagement (X1), Job Satisfaction (X2), and Organizational Change (Y1) have a significant effect on the endogenous variables of Organizational Effectiveness. (Y2).

\section{b. Hypothesis testing}

1) Effect of $X 1$ and $X 2$ on $Y 1$.

The results of the standardized regression test are shown in the table below: 
International Journal of Advances in Scientific Research and Engineering (ijasre), Vol 6 (9), September -2020

Table 2. Regression Analysis Results of the Effect of X1 and X2 on Y1

\begin{tabular}{|l|l|l|l|l|}
\hline \multicolumn{1}{|c|}{ Variable } & Beta & thitung & \multicolumn{1}{c|}{ sig } & \multicolumn{1}{c|}{ Information } \\
\hline Employee Engagement (X1) & 0.129 & 1,357 & 0.178 & Not significant \\
\hline Job Satisfaction (X2) & 0.284 & 2,979 & 0.004 & Significant \\
\hline $\mathrm{t}$ (table) & $=1,982$ \\
R Square & $=0.121$ \\
\hline
\end{tabular}

Based on table 2 above, it can be concluded that:

$>$ The results of testing the influence of the Employee Engagement (X1) and Job Satisfaction (X2) variables on Organizational Change (Y1) have an R Square of 0.121 or a determination coefficient (KD) of $12.1 \%$, meaning that the Organizational Change variable (Y1) can only be explained by the Employee variable. Engagement (X1) and Job Satisfaction (X2) were $12.1 \%$, while the remaining $87.9 \%$ was influenced by variables outside the independent variables under study.

Standardize regression equation:

$\mathrm{Y} 1=0.129 \mathrm{X} 1+0.284 \mathrm{X} 2+\varepsilon \mathrm{i}$

From the tcount value shows that:

$\checkmark$ The Employee Engagement variable (X1) has a positive but not significant effect on the organizational change variable (Y1). With a t-count value that is smaller than $\mathrm{t}$-table $(1.357<1.982)$ or a sig value that is greater than $\alpha(0.178>0.050)$. The positive coefficient shows that the Employee Engagement (X1) variable can increase the Organizational Change (Y1) variable but it is not significant.

$\checkmark$ Job Satisfaction Variable (X2) has a positive and significant effect on the Organizational Change variable (Y1). With a tcount value that is smaller than t-table $(2.979>1.982)$ or a sig value that is greater than $\alpha(0.004<0.050)$. The positive coefficient shows that the Job Satisfaction variable (X2) can significantly increase the Organizational Change (Y1) variable.

2) Effect of X1, X2 and Y1 on Y2

The results of the standardized regression test are shown in the table below:

Table 3.Results of the Regression Analysis of the Effect of X1, X2 and Y1 on Y2

\begin{tabular}{|l|l|l|l|l|}
\hline Variable & Beta & thitung & sig & Information \\
\hline Employee Engagement (X1) & 0.278 & 3,547 & 0.001 & Significant \\
\hline Job Satisfaction (X2) & 0.386 & 4,775 & 0.000 & Significant \\
\hline Organizational Change (Y1) & 0.215 & 2,743 & 0.007 & Significant \\
\hline t (table) & $=1,982$ & & \\
R Square & $=0.421$ & & \\
\hline
\end{tabular}

Based on table 3 above, it can be concluded that:

$>$ From the value of R Square shows a value of 0.421 or $42.1 \%$. This means that the Organizational Effectiveness (Y2) variable can be explained by the variables of Employee Engagement (X1), Job Satisfaction (X2), and Organizational Change (Y1) by $42.1 \%$, while the remaining $57.9 \%$ is influenced by variables outside the independent variables studied.

$>$ Standardize regression equation:

$\mathrm{Y} 2=0.278 \mathrm{X} 1+0.386 \mathrm{X} 2+0.215 \mathrm{Y} 1+\varepsilon \mathrm{i}$

From the tcount value shows that:

$\checkmark$ Employee Engagement variable (X1) has a positive and significant effect on the Organizational Effectiveness variable (Y2). With a tcount value that is greater than ttable $(3.547>1.982)$ or a sig value that is smaller than $\alpha(0.001<0.050)$. The positive coefficient indicates that the Employee Engagement variable (X1) can significantly increase the Organizational Effectiveness (Y2) variable.

$\checkmark$ Job Satisfaction Variable (X2) has a positive and significant effect on the Organizational Effectiveness variable (Y2). With a t-count value that is greater than t-table $(4.775>1.982)$ or a sig value that is smaller than $\alpha(0.000<0.050)$. The positive coefficient shows that the Job Satisfaction variable (X2) can significantly increase the Organizational Effectiveness (Y2) variable.

$\checkmark$ Organizational Change Variable (Y1) has a positive and significant effect on the Organizational Effectiveness variable (Y2). With a tcount value greater than ttable $(2.743>1.982)$ or a sig value smaller than $\alpha(0.007<0.050)$. The positive coefficient indicates that the Organizational Change variable (Y1) can significantly increase the Organizational Effectiveness (Y2) variable.

\section{c. Interpretation of Path}

From the two equations above, the overall path analysis results are as follows: 


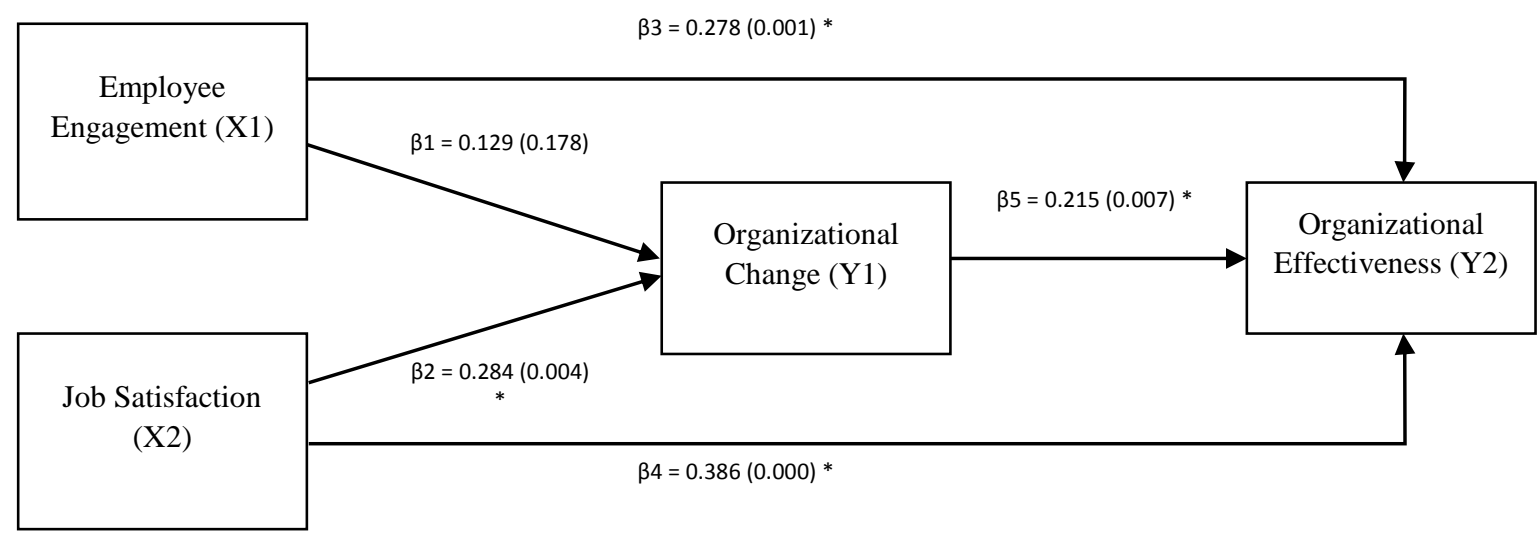

Figure 2. Path diagram of the theoretical model of path interpretation research

From Figure 2 above and the explanation in the previous explanation, the Goodness of Fit model is tested using the total coefficient of determination. The total diversity of data that can be explained by the model is measured by the formula:

$\mathrm{R} 2 \mathrm{~m}=1$ - P2e1 P2e2... .P2ep

Where :

$\mathrm{P} 2 \mathrm{e} 1=1-\mathrm{R} 21 ; \quad \mathrm{P}^{2 \mathrm{e} 2}=1-\mathrm{R} 22$

$\mathrm{R} 21$ is the $\mathrm{R}$ square for equation 1 which is equal to 0.121 ,

$\mathrm{R} 22$ is the $\mathrm{R}$ square for equation 2 which is equal to 0.421 :

$\mathrm{P} 2 \mathrm{e} 1=1-0.121=0.879$;

$\mathrm{P} 2 \mathrm{e} 2=1-0.421=0.579$

So that the total coefficient of determination is obtained as follows:

$\mathrm{R} 2 \mathrm{~m}=1-(0.879 \times 0.579)=0.491$ or $49.1 \%$

The results of the $\mathrm{R} 2 \mathrm{~m}$ calculation indicate that the diversity of data that can be explained by the model is 0.491 , or in other words, the information contained in the $49.1 \%$ data can be explained by the model. Meanwhile, the remaining $50.9 \%$ of the diversity is explained by other variables (which are not included in the model).

Overall, the model in this study is divided into 5 direct effects and 2 indirect effects. The following table presents the results of testing the direct effect and indirect effect:

Table 4. Hypothesis Testing Results Direct Effect

\begin{tabular}{|c|c|c|c|c|}
\hline Exogenous Variables & Endogenous Variables & Path & sig & Information \\
\hline X1 & Y1 & 0.129 & 0.178 & Not significant \\
\hline X2 & Y1 & 0.284 & 0.004 & Significant \\
\hline X1 & Y2 & 0.278 & 0.001 & Significant \\
\hline X2 & Y2 & 0.386 & 0.000 & Significant \\
\hline
\end{tabular}

Table 5. Hypothesis Testing Results of Indirect Effect

\begin{tabular}{|c|c|c|c|c|}
\hline $\begin{array}{c}\text { Exogenous } \\
\text { Variables }\end{array}$ & Intermediate Variable & $\begin{array}{c}\text { Endogenous } \\
\text { Variables }\end{array}$ & Path & Information \\
\hline X1 & Y1 & Y2 & 0.028 & Not significant \\
\hline X2 & Y1 & Y2 & 0.610 & Significant \\
\hline
\end{tabular}

\subsection{Discussion of Research Results}

4.2.1. Effect of Employee Engagement (X1) and Job Satisfaction (X2) on Organizational Change (Y1) in the Technical Implementation Unit of the Regional Public Service Agency (BLUD) in the Department of Agriculture and Food Security, East Java Province

Based on the results of research that has been done, it can be concluded that employee engagement has no significant effect on organizational change. These findings reject the research conducted by (Zulkarnain \& Hadiyani, 2014) [14], where in his research it confirmed that employee engagement contributes to organizational change, as well as research conducted by (Simbolon, 2018) which said that there was a positive effect of employee engagement on employee readiness in facing organizational change [15]. Related to these results, although employee engagement has no significant effect on organizational change, it can specifically support organizational effectiveness, this is based on the descriptive analysis results previously explained, that in fact there is a feeling of pride from employees being able to work in the UPT BLUD, apart from The employees are sufficiently committed to the goals of the organization, and motivated to contribute or support the success of the organization and are willing to work more by, for example, helping superiors or other sections. 
Khan (1990) emphasizes that the key to employee engagement is the involvement of employees in the company where employees can position themselves to be actively involved in the processes that occur in the organizational environment, so based on this it can be understood if the results of the study show that employee engagement has no significant effect. against organizational change, because in reality the process of changing UPT to BLUD is a top down decision, and employees are not involved in making the policy [16].

But it needs to be underlined that based on the statement from the Chief Executive Officer of GML Performance Consulting, as quoted from the online site Kontan.co.id at the 2019 SWP Award event, that Employee engagement is one of the factors that affect the sustainability of a company. The existence of an attachment between employees and the company is important, considering that human resources are actually an intangible asset that is very important for the progress of the company itself. Quality in HR management is the main requirement in the successful execution of a strategy in a company. The higher the employee engagement level, the higher the employee productivity.

Furthermore, related to job satisfaction, based on the results of the study, there is a significant influence on organizational change. These findings support or are in accordance with the results of previous research conducted (Adigwe \& Oriola, 2015) which states that job satisfaction has a significant effect on organizational change [17].

Still related to job satisfaction, that the findings in the study are also in accordance with the results of previous research produced by (Yousef, 2017), which results in the conclusion that certain aspects of job satisfaction have direct and indirect effects (through various dimensions of organizational commitment. ) towards organizational change, it is further explained that increasing job satisfaction through, for example, designing an incentive program will result in increased employee commitment to their current department and consequently they will be more supportive in the organizational change process [18]. The reality in the field is that starting from 2019 there are additional incentives or performance allowances for employees within the UPT BLUD, so that employees feel that they get appreciation for their work according to what they are trying to do, so that the incentive program is considered successful, besides that a more efficient job description is very support in organizational change.

Employee satisfaction in work is indeed something that is desired by both management and employees personally, so according to Lutans, several things can be done to improve this, namely making the work done fun, then getting a proper salary and fair promotion opportunities, then placing employees according to their interests and skills, and design jobs to make it interesting and satisfying [8].

\subsubsection{The Effect of Employee Engagement and Job Satisfaction on Organizational Effectiveness in the Technical Implementation Unit of the Regional Public Service Agency (BLUD) in the Department of Agriculture and Food Security, East Java Province}

Based on the results of the research that has been conducted, it is concluded that employee engagement is proven to have a significant effect on Organizational Effectiveness. The results of this study support the findings of previous research conducted by (Sundaray, 2011), which states that employee engagement is a driving factor for the effectiveness of an organization, so that employee engagement is a positive factor for an organization and is very important to grow in the work environment to help the organization in realizing the mission of the organization [19]. Previous previous research produced by (Jha et al., 2019)) [20] and (Shahid \& Azhar, 2013) [21], also states that there is a close relationship between employee involvement and organizational effectiveness, as well as several factors from employees who are committed to their organization, namely that the employee feels attached to his job and also feels satisfaction at work.

Then the effect of job satisfaction with organizational effectiveness, based on the results of the research also proved that there is a significant effect. These results support previous research conducted by (Appelbaum et al., 2017) [22] which explains that one of the supporting factors in organizational change is employee satisfaction, also research from (Koys, 2001) [23] which concluded that there is a positive relationship between job satisfaction and organizational effectiveness, as well as research from (Shahid \& Azhar, 2013) [21] which highlights related to employee commitment has a positive effect on organizational effectiveness, where several factors from employees who are committed to the organization are that the employee feels attached to his job and also feels satisfaction at work.

In general, employee involvement is closely related to the performance results of an organization, companies with high employee involvement cause reduced intention to leave the company, encourage increased productivity, profitability, growth and organizational sustainability and can increase customer satisfaction (Kompaso \& Sridevi, 2010) [24]. To support the effectiveness of this organization, based on research, information is also obtained, that since 2018, there have been additional performance allowances for all employees in the East Java provincial government, besides that with the ease or flexibility in budget management, it is hoped that it will foster employee satisfaction with their work, so that efforts to increase organizational effectiveness can be achieved. In addition to the incentives from the research results, the results also show that organizations are trying to make the atmosphere of the work environment comfortable by renovating the room according to their respective sections, rejuvenating air conditioners that are no longer suitable for use, in addition to updating old computer devices. make work easier. 


\subsubsection{The Effect of Organizational Change on Organizational Effectiveness in the Technical Implementation Unit of the} Regional Public Service Agency (BLUD) in the Department of Agriculture and Food Security, East Java Province.

Based on the results of the research that has been done, it is concluded that Organizational Change is proven to have a significant effect on Organizational Effectiveness in the Technical Implementation Unit of the Regional Public Service Agency (BLUD). The results obtained are in accordance with previous research conducted by (Munir Y, Nazir T, Fida S, 2013) [25] One of the conclusions obtained is that organizational change has a close relationship with organizational effectiveness, as well as research from (Soegiono and Sutanto, 2013) [26] which highlights related to structural changes, which are said to be able to provide benefits for the company, which include increasing company efficiency, strengthening company competitiveness, increasing faster growth in business, especially internal growth rates, and increasing the productivity of the company's assets. Based on the results of the research that in the organizational changes that occurred within the UPT Office of Agriculture and Food Security of East Java Province, not only did the status change become BLUDs, but also accompanied by changes in organizational structure, namely the Head of UPT BLUD assisted by the Head of Subdivision of Administration who was responsible. responsible for administration, and as the function of the coordinator for the other two sections, namely the Production Section which is responsible for the production process and the Marketing Section which is responsible for product marketing and cooperation development, so that it is evident from the changes that the expected organizational effectiveness is achieved. This is also in accordance with the statement from (Paul D. Sweeney and Dean B. Mcfarlin, 2002), who said that a change that is common today is simplifying the bureaucracy so that decision making can be simpler, besides increasing the initiative or participation of employees. in encouraging growth and organizational effectiveness so that it is proven by the change that the expected organizational effectiveness is achieved. This is also in accordance with the statement from (Paul D. Sweeney and Dean B. Mcfarlin, 2002), who said that the change that is common today is simplifying the bureaucracy so that decision making can be simpler, besides increasing the initiative or participation of employees. in encouraging growth and organizational effectiveness so that it is proven by the changes that the expected organizational effectiveness is achieved. This is also in accordance with the statement from (Paul D. Sweeney and Dean B. Mcfarlin, 2002), who said that the change that is common today is simplifying the bureaucracy so that decision making can be simpler, besides increasing the initiative or participation of employees. in encouraging growth and organizational effectiveness [27].

Organizational changes within the UPT BLUD which in fact occur dramatically, due to government regulations and must be addressed in a professional manner, will be able to encourage effectiveness in the organization, this is in line with what (Simsek \& Louis, 1994) suggests, namely that without there is a dramatic change in the environment, the organization will only make slower adaptive changes, and it will slow down organizational performance.

According to (Greenberg, 2005), one of the factors that drives organizational change, namely regulations from the government, it is said that this regulatory change results in unplanned organizational changes, but with the support of the right incentives, as well as efforts to streamline work mechanisms, organizational changes for adjusting to the new regulations can run well and in accordance with expectations in its formation [28].

The fact of the research results, that associated with organizational change, in the end can make work more effective, this is because the span of control in decision making is shorter, especially related to budget management. Budgeting can be done directly and independently as needed. The speed of disbursement of the budget is also faster because it does not have to be compiled first at the Provincial Agriculture and Resilience Agency level and then disbursement is submitted to the treasury, but by becoming a BLUD it can be directly related to the treasury. In addition, related to the optimization of the use of assets that are owned easier,

\subsubsection{The Effect of Employee Engagement and Job Satisfaction on Organizational Effectiveness through Organizational Change in the Technical Implementation Unit of the Regional Public Service Agency (BLUD) in the Department of Agriculture and Food Security, East Java Province}

Employee Engagement and Job Satisfaction of employees greatly influence Organizational Effectiveness, then job satisfaction also supports organizational change, so that employee job satisfaction and organizational changes are more influential than if there was no organizational change. But on the other hand, those related to employee engagement tend to have a big influence on organizational effectiveness if directly, without any organizational changes. This could be because prior to the change in the organization, employees felt proud of their organization, moreover, organizational changes are still in the process of looking for the best form, so that employee engagement can be grown to be able to support during the final process of organizational changes that occur.

Every work organization can be ensured that it will always pay more attention to effectiveness with the hope that it will be able to support efforts to achieve organizational goals and objectives and maintain the continuity and future of the organization (Mullins, 2011) [1]. In maintaining organizational effectiveness, the organization must also adapt to any changes, including organizational changes. This relates to the ability of management to predict or respond to changes in the environment and within the organization itself. Changes that occur in the organization also involve employees as human resources. Employee engagement is one of the important concepts in organizational behavior (Hanaysha, 2016) [7]. 
Satisfaction as an indicator of effectiveness refers to the success or extent to which the organization meets the needs of its employees or members. Satisfaction measures include employee attitudes, employee turnover, attendance, tardiness, and complaints. From the organizational side related to this organizational change, it can also encourage or improve the performance of the organization, where the faster an organization can adapt to the demands for change, it will be able to improve the performance of the organization.

Organizational change is not a significant factor mediating employee engagement on organizational effectiveness, it could occur because of the organizational change process that occurs due to regulatory factors from the government to make changes, not an encouragement from within the organization, or in the process employees are not directly involved. which in the end, these employees will become the backbone in the success of changes that occur in the organizational environment. But even so, with the existence of job satisfaction in the scope of employees, through organizational changes there are efforts to adapt quickly to regulatory changes, and add appropriate incentives to employees and increase work effectiveness,

\section{CONCLUSIONS AND RECOMMENDATIONS}

\subsection{Conclusion}

1) Employee engagement at UPT BLUD in the scope of the Department of Agriculture and Food Security of East Java Province, is much influenced by the absorption of employees for their work, this is reflected in the attitude of employees who enjoy the work they are doing, so that time seems to pass quickly for them, when busy with work. Furthermore, employee job satisfaction is influenced by supervision that goes well and is positively addressed by employees, this can be seen from the attitude of superiors who are willing to accept suggestions from subordinates so that there is two-way communication between employees and superiors, as well as motivation / guidance from superiors to their subordinates. very helpful to increase job satisfaction, this is because employees feel there is concern from their superiors for what they are doing so they feel comfortable at work. Then for Organizational Change, the dominant factor that influences and can be felt directly for employees is a change in the physical arrangement of the work environment, so that it becomes more beautiful and comfortable for employees to work, then the use of technology to support increased performance is also very important to pay attention to in the digital era such as nowadays, where computerization is commonplace it is even a necessity. As for organizational effectiveness, the most influential thing is employee satisfaction, which is related to the organization's ability to increase employee income, as well as create a comfortable work environment for employees.

2) Employee Engagement is not able to have a positive influence on organizational change, this is because organizational changes that occur are dramatic and tend to be sudden, without direct employee involvement in the process, but on the other hand, it turns out that employee job satisfaction can have a positive impact on change. organization, this is because even though there is a feeling of compulsion in carrying out the change process that occurs, employees get additional incentives or honorariums in their work, besides that with flexibility in budget use, efforts to rejuvenate or improve the office environment to create comfort in work can be easy to do .

3) With regard to Employee Engagement and Job Satisfaction, it turns out to be very influential on organizational effectiveness, this is reflected in employees who feel proud of the work they do, besides that the comfort of their physical work environment and good relationships with colleagues also greatly affects organizational effectiveness. so that employees feel that they belong to the organization, because the work they do supports the organization to be able to meet performance targets in accordance with its main duties.

4) Organizational changes significantly affect organizational effectiveness, which is illustrated, namely the flexibility in budget management, then granting rights as asset managers directly so that they can take advantage of the capacity and potential of their assets for organizational progress, recognition of the organization as an independent entity and no longer waiting and depending on the parent agency and allowing him to diversify his business outside his core business in order to increase the income of the organization.

5) Employee Engagement and Job Satisfaction of employees greatly influence Organizational Effectiveness, then job satisfaction also supports organizational change, so that employee job satisfaction and organizational changes will have a bigger impact than if there was no organizational change. But on the other hand, those related to employee engagement tend to have a big influence on organizational effectiveness if directly, without any organizational changes. This could be because prior to the change in the organization, employees felt proud of their organization, moreover, organizational changes are still in the process of finding the best form.

\subsection{Suggestion}

1) For the Department of Agriculture and Food Security in general and UPT. which turned into a BLUD in particular.

The addition of new tasks and main functions as well as various kinds of advantages in the process of organizational change that occurs, must be utilized properly in order to increase organizational effectiveness, especially in the UPT BLUD, this can be done by optimizing power over the use of assets, namely in the form of productive land owned, and combined with power related to the use and preparation of the budget, so that efforts to diversify the business by using 
the productive land assets owned can be fully supported by a budget that is in accordance with the needs and timely disbursement so that it is in accordance with the conditions or requests in the field. In addition to that, employee engagement is deemed necessary, so that it can support all kinds of policy changes or rules that occur in the organization. Job satisfaction of employees must be maintained and as much as possible to be improved so that it can have a positive impact on the achievement of organizational goals.

2) For the Development of Science

With regard to employee engagement, further research is needed regarding its effect on organizational change, for example in organizations that have completed the organizational change process so that the impact can be clearly identified. In addition, carrying out the process of changing an organization should involve all parties who are competent in this matter, not only decision makers but also employees in general, which in the end these employees will later run and become the backbone of the success or failure of the organizational change.

3) For Further Research

In this study, of course, there are shortcomings and limitations so that what is produced here is expected to be the basis of reference for continuing further research, especially those related to factors - other supporting factors that affect organizational effectiveness also need to be further investigated and also reassure related employee engagement relationships. with organizational change, which ensures in advance that employees in general are directly involved in the organizational change process.

\section{REFERENCES}

1. Mullins, L. J. (2011). Approaches to Organisation and Management. Essentials of Organisational Behaviour.

2. Robbins, Stepen P, \& Judge, T. A. (2008). Perilaku organisasi edisi ke-12. In Chemical and Petroleum Engineering.

3. Fatimah, O., Amiraa, A. M., \& Halim, F. W. (2011). The relationships between organizational justice, organizational citizenship behavior and job satisfaction. Pertanika Journal of Social Science and Humanities.

4. Robinson, D., Perryman, S., \& Hayday, S. (2004). The Drivers of Employee Engagement. North. https://doi.org/IES Report No. 408.

5. Gruman, J. A., \& Saks, A. M. (2011). Performance management and employee engagement. Human Resource Management Review. https://doi.org/10.1016/j.hrmr.2010.09.004

6. Lukman, M. (2013). Badan Layanan Umum dari Birokrasi Menuju Korporasi. Jakarta: Bumi Aksara.

7. Hanaysha, J. (2016). Testing the Effects of Employee Engagement, Work Environment, and Organizational Learning on Organizational Commitment. Procedia - Social and Behavioral Sciences, $229, \quad 289-297$. https://doi.org/10.1016/j.sbspro.2016.07.139

8. Luthans, F. (2012). Organizational behavior an evidence-based approach 12th edition. In Organizational behavior: an edivence-based approach.

9. Irianto, J. (2011). Manajemen Sumber Daya Manusia Sektor Publik di Indonesia : Pengantar Pengembangan Model MSDM Sektor Publik. Jurnal Kebijakan Dan Administrasi Publik.

10. Gibson, J. L., Ivancevich, J. M., \& Donnelly, J. H. (1989). Organisasi : perilaku, struktur, proses, jilid 2. In Organisasi.

11. Triatmanto, B., \& Nursyamsi, I. (2011). Strategic Human Resources Management, Organizational Change , Organizational Resilience and Improvement of Organization Performance. (2002).

12. Nelson, L. (2003). A case study in organisational change: Implications for theory. The Learning Organization. https://doi.org/10.1108/09696470310457478

13. Sugiyono. (2017). Statistika untuk Penelitian. Bandung: Alfabeta.

14. Zulkarnain, -, \& Hadiyani, S. (2014). Peranan Komitmen Organisasi dan Employee Engagement terhadap Kesiapan Karyawan untuk Berubah. Jurnal Psikologi. https://doi.org/10.22146/jpsi.6955

15. Simbolon, H. (2018). PENGARUH EMPLOYEE ENGAGEMENT TERHADAP KESIAPAN MENGHADAPI PERUBAHAN ORGANISASI. PSIKODIMENSIA. https://doi.org/10.24167/psiko.v16i2.1183

16. Kahn, W. A. (1990). Psychological conditions of personal engagement and disengagement at work. Academy of Management Journal. https://doi.org/10.5465/256287

17. Adigwe, I., \& Oriola, J. (2015). Towards an understanding of job satisfaction as it correlates with organizational change among personnel in computer-based special libraries in Southwest Nigeria. Electronic Library. https://doi.org/10.1108/EL01-2014-0018

18. Yousef, D. A. (2017). Organizational Commitment, Job Satisfaction and Attitudes toward Organizational Change: A Study in the Local Government. International Journal of Public Administration, 40(1), 77-88. https://doi.org/10.1080/01900692.2015.1072217

19. Sundaray, B. K. (2011). Employee Engagement: A Driver of Organizational Effectiveness. European Journal of Business and Management, 3(8), 53-60.20. Jha, N., Potnuru, R. K. G., Sareen, P., \& Shaju, S. (2019). Employee voice, engagement and organizational effectiveness: a mediated model. European Journal of Training and Development. https://doi.org/10.1108/EJTD-10-2018-0097

20. Jha, N., Potnuru, R. K. G., Sareen, P., \& Shaju, S. (2019). Employee voice, engagement and organizational effectiveness: a mediated model. European Journal of Training and Development. https://doi.org/10.1108/EJTD-10-2018-0097

21. Shahid, A., \& Azhar, S. M. (2013). Gaining Employee Commitment: Linking to Organizational Effectiveness. Journal of Management Research. https://doi.org/10.5296/jmr.v5i1.2319 
22. Appelbaum, S. H., Cameron, A., Ensink, F., Hazarika, J., Attir, R., Ezzedine, R., \& Shekhar, V. (2017). Factors that impact the success of an organizational change: a case study analysis. Industrial and Commercial Training. https://doi.org/10.1108/ICT-02-2017-0006

23. Koys, D. J. (2001). The effects of employee satisfaction, organizational citizenship behavior, and turnover on organizational effectiveness: A unit-level, longitudinal study. Personnel Psychology. https://doi.org/10.1111/j.1744-6570.2001.tb00087.x

24. Kompaso, S. M., \& Sridevi, M. S. (2010). Employee Engagement: The Key to Improving Performance. International Journal of Business and Management. https://doi.org/10.5539/ijbm.v5n12p89

25. Munir Y, Nazir T, Fida S, et al. (2013). The impact of Organizational Stress, Knowledge Management , and Organizational Change on Organizational Effectiveness. International Journal of Management Science, 1(3), 83-89.

26. Soegiono dan Sutanto. (2013). Restrukturisasi organisasi di pt samudra alam raya surabaya. Agora, 1(3).

27. Paul D. Sweeney dan Dean B. Mcfarlin. (2002). Organization Behaviour : Solution for Management. New York: McGrawHill.

28. Greenberg, J. (2005). Managing Behavior in Organizations 4th Edition (4th ed.). New Jersey: Pearson Prentice Hall. 